Soeprapto Rakhmat, dkk., Pembelajaran Pelafalan Bahasa Perancis

\title{
PEMBELAJARAN PELAFALAN BAHASA PERANCIS MELALUI MODEL ARTIKULATORIS PENGEMBANGAN (MAP) BERBASIS MULTIMEDIA INTERAKTIF
}

\author{
Soeprapto Rakhmat \\ Yuliarti Mutiarsih \\ Dante Darmawangsa \\ Departemen Pendidikan Bahasa Perancis FPBS UPI \\ Korespondensi: Jl. Dr. Setiabudhi 229 Badung 40154 \\ Pos-el: soepraptorakhmat@gmail.com
}

\begin{abstract}
Abstrak
Penelitian ini merupakan kajian untuk merancang dan mengembangkan model pembelajaran pelafalan bahasa Perancis, yaitu model artikulatoris pengembangan (MAP) berbasis teknologi multimedia CD-ROM Interaktif. Kajian ini dilakukan untuk melakukan penyempurnaan dan inovasi berupa pengintegrasian teknologi multimedia dan MAP dalam pembelajaran pelafalan bahasa Perancis. Penelitian ini mengkaji (1) perancangan dan pengembangan model pembelajaran Artikulatoris Pengembangan yang berbasis multimedia CD-ROM dalam pembelajaran pelafalan bahasa Perancis; (2) pemerolehan data empirik mengenai efektivitas penerapan model tersebut dalam pembelajaran pelafalan bahasa Perancis, (3) kendala yang dihadapi oleh para pembelajar selama proses pembelajaran. Metode penelitian yang digunakan adalah Research \& Development. Adapun langkahlangkah yang peneliti tempuh dalam melaksanakan penelitian ini terdiri dari tiga tahap, yaitu (1) Studi Pendahuluan, (2) Perencanaan dan Pengembangan Model, dan (3) Validasi Model. Hasil penelitian menunjukkan bahwa MAP berbasis multimedia CD-ROM terbukti efektif dalam meningkatkan kualitas pembelajaran pelafalan bahasa Perancis. Hasil penelitian menunjukkan pula terdapat 2 (dua) jenis kesalahan pelafalan mahasiswa, yaitu secara fonologis dan secara artikulatoris. Kedua kesalahan tersebut diakibatkan oleh

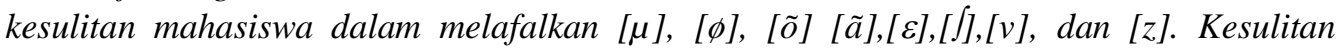
secara fonologis dipengaruhi oleh penguasaan bahasa sebelumnya, sementara kesalahan secara artikulatoris mahasiswa tidak memfungsikan alat ucap secara tepat dan optimal.
\end{abstract}

Kata-kata kunci: Model pembelajaran pelafalan, bahasa Perancis, MAP

\begin{abstract}
This research is aimed to design and develop a teaching model of French pronunciation, namely the model of interactiveCD-ROMmultimedia-based articulatory development. The study was undertaken to make improvements and innovations, such as the integration of multimedia technology and the articulatory model in teaching French pronunciation. This study presents data concerning (1) the design and development of the model; (2) the empirical data on the effectiveness of the application of the model in teaching French pronunciation, (3) the constraints faced by the learner during the learning process. The method used was Research \& Development, which consisted of three phases, namely: (1) preliminary study, (2) planning and development of the model and (3) validation of the model. Results show that the model in question proved to be effective in improving the quality of learning French pronunciation. In addition, results show there were two types of student pronunciation errors, phonological and articulatory. Both are caused by the difficulty in pronouncing $[\mu],[\phi],[\tilde{\sigma}][\tilde{a}],[\varepsilon],[\delta],[v]$, and [z]. Phonological difficulties are influenced by first language interference, while articulatory difficulties are caused by students not using their articulatory tracts properly and optimally.
\end{abstract}

Keywords: Pronunciation teaching model, French, articulatory model of development 


\section{PENDAHULUAN}

Indonesia sebagai negara kepulauan telah melahirkan beragamnya budaya dan bahasa daerah. Oleh sebab itu, orang Indonesia pada akhirnya dapat dikatakan sebagai seorang dwibahasawan, karena ia tumbuh dengan bahasa daerahnya dan tentunya bahasa Indonesia sebagai bahasa resmi dan persatuan. Belum lagi ditambah dengan dipelajarinya bahasa asing di sekolah-sekolah maupun perguruan tinggi ataupun lembaga pendidikan lainnya.

Banyak ahli berpendapat tentang pengertian kedwibahasaan, namun dapat disimpulkan bahwa kedwibahasaan adalah penguasaan dan penggunaan dua bahasa atau lebih oleh seorang penutur.Dalam keadaan bahasa berkontak ada kecenderungan pada dwibahasawan untuk mempersamakan hal-hal yang ada pada bahasa satu dengan hal-hal yang ada pada bahasa lain, bahkan kadang-kadang terjadi pencampurbauran kedua sistem bahasa sehingga terjadi interferensi.

Bahasa Perancis, sebagai salah satu bahasa asing yang diajarkan di Indonesia, merupakan salah satu bahasa yang memiliki sistem bunyi yang cukup kompleks untuk dipelajari. Interferensi

1. [ i ] seperti dalam kata nid [ni] artinya sarang

2. [y] seperti dalam kata r $\underline{u} e$ [ry] artinya jalan

3. [u] seperti dalam kata $\underline{\operatorname{loup}}[\mathrm{lu}]$ artinya serigala

4. [e] seperti dalam kata dé [de] artinya dadu

5. [ع] seperti dalam kata dès $[\mathrm{d} \varepsilon]$ artinya sejak

6. $[\varnothing]^{*}$ seperti dalam kata $\underline{\underline{e u}} \underline{x}[\mathrm{p} \varnothing]$ artinya dapat

7. [œ]*seperti dalam kata peur [pœr] artinya takut

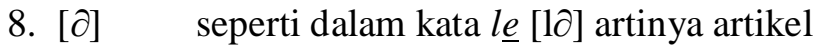

9. [o] seperti dalam kata pot [po] artinya poci

10.[ ] seperti dalam kata fort [f r] artinya kuat

11.[a] seperti dalam kata part [par] artinya berangkat

12.[a] seperti dalam kata $p$ âte [ pat] artinya kaki binatang kerap muncul baik itu dari sistem bunyi konsonan maupun vokal yang disebabkan oleh latar belakang penguasaan bahasa pertama, misalnya bahasa sunda atau bahasa Indonesia, maupun oleh latar belakang penguasaan terhadap bahasa nggris. Fakta mengenai hal ini telah ditunjukkan oleh hasil penelitian Mutiarsih (2009). Sekaitan dengan hal tersebut, maka kiranya diperlukan sebuah model pembelajaran pelafalan yang dapat membantu memecahkan permasalahanpermasalahan di atas.

Sekaitan dengan system pelafalan dalam bahasa Perancis, terdapat tiga kelas bunyi yaitu vokal, konsonan, dan semi vokal atau semi konsonan (GardesTamine, 1990:9).Dalam bahasa tulisan dan bahasa lisan, pengertian graphie dan phonie bahasa Perancis tidak seperti dalam bahasa Indonesia yang umumnya memerlukan satu fon untuk satu graf saja. Dalam bahasa Perancis satu fon mungkin ditulis dalam beberapa graf.Bahasa Perancis memiliki 16 vokal yang terdiri tas 12 vokal oral yaitu [ i ], [ $\varepsilon$ ], [ e ], [ a ], [a], [ o ], [ ], [ u ], [ y ] [ø], [œ], [ $\partial$ ], dan 4 vokal sengau atau nasal yaitu $[\varepsilon]$, a], [œ], [ õ], serta 3 semi vokal yaitu [j], [ [w]. Berikut ini contoh vokal oral. 
* Lambang [ø] merupakan lambang bunyi fonem bahasa Perancis yang dilafalkan pada suku kata tertutup, sedangkan lambang [œ] merupakan lambang bunyi fonem pada suku kata terbuka.

Selain vocal oral, berikut ini contoh vokal nasal atau sengau

13. $[\varepsilon]$ seperti dalam kata $\underline{v i n}[\mathrm{v} \varepsilon]$ artinya minuman anggur

14.[œ] seperti dalam kata parfum [parfœ] artinya minyak wangi

15.[õ] seperti dalam kata long[lõ] artinya panjang

16. [a] seperti dalam kata $\underline{a n}[\mathrm{a}]$ artinya tahun

Bunyi vocal lainnya adalah semi vokal seperti contoh berikut.

1. [j] seperti dalam kata hier [je:R] artinya kemarin

2. [ ] seperti dalam kata nuit [n ] artinya malam

3. [w] seperti dalam kata voiture [vwatyR] artinya mobil

Dalam kamus Robert (2006) bahasa Perancis memiliki 20 konsonan yaitu [p],[t], $[\mathrm{k}],[\mathrm{b}][\mathrm{d}],[\mathrm{g}],[\mathrm{f}],[\mathrm{s}],[\mathrm{v}],[\mathrm{z}],[\mathrm{l}],[\mathrm{R}],[\mathrm{m}],[\mathrm{n}],[3],[\mathrm{n}][\mathrm{C}],[\mathrm{h}],[\mathrm{y}],[\mathrm{x}]$.

1. [p] seperti dalam kata soupe [sup] artinya sup

2. [t] seperti dalam kata vite [vit] artinya cepat

3. [k] seperti dalam kata kiwi [kiwi] artinya buah kiwi

4. [b] seperti dalam kata robe [Rob] artinya gaun

5. [d] seperti dalam kata dè̀s [de] artinya sejak

6. [g] seperti dalam kata garçon [garsõ] artinya anak laki-laki

7. [f] seperti dalam kata neuf [nøf] artinya sembilan

8. [s]seperti dalam kata sale [sal] artinya kotor

9. [v]seperti dalam kata rêve [R\&v] artinya mimpi

10.[z]seperti dalam kata [Roz] artinya bunga ros

11.[1]seperti dalam kata lent [lã] artinya pelan

12.[R]seperti dalam kata rue [Ry]artinya jalan

13.[m] seperti dalam kata manger [mãze] artinya makan

14.[n] seperti dalam kata vigne [vin] artinya anggur

15.[3] seperti dalam kata je [3ə] artinya saya

16.[n] seperti dalam kata animal [animal] artinya binatang

17.[S] seperti dalam kata chat [ [ a ]artinya kucing

18.[h] seperti dalam kata hôtel [hotel] artinya hotel

19.[n]seperti dalam kata camping [kãpin] artinya camping

20. [x] seperti dalam kata deuxième [døzijem] artinya kedua 
Model

Pengembangan pembelajaran dikembangkan dalam penelitian Mutiarsih (2009) dari model artikulatoris DELBART-PAGNIEZ. Model Artikuatoris Pengembangan menampilkan bagan bagian muka sebelah kiri dengan menunjukkan titik tempat artikulasi, dan cara kerja alat ucap dalam proses

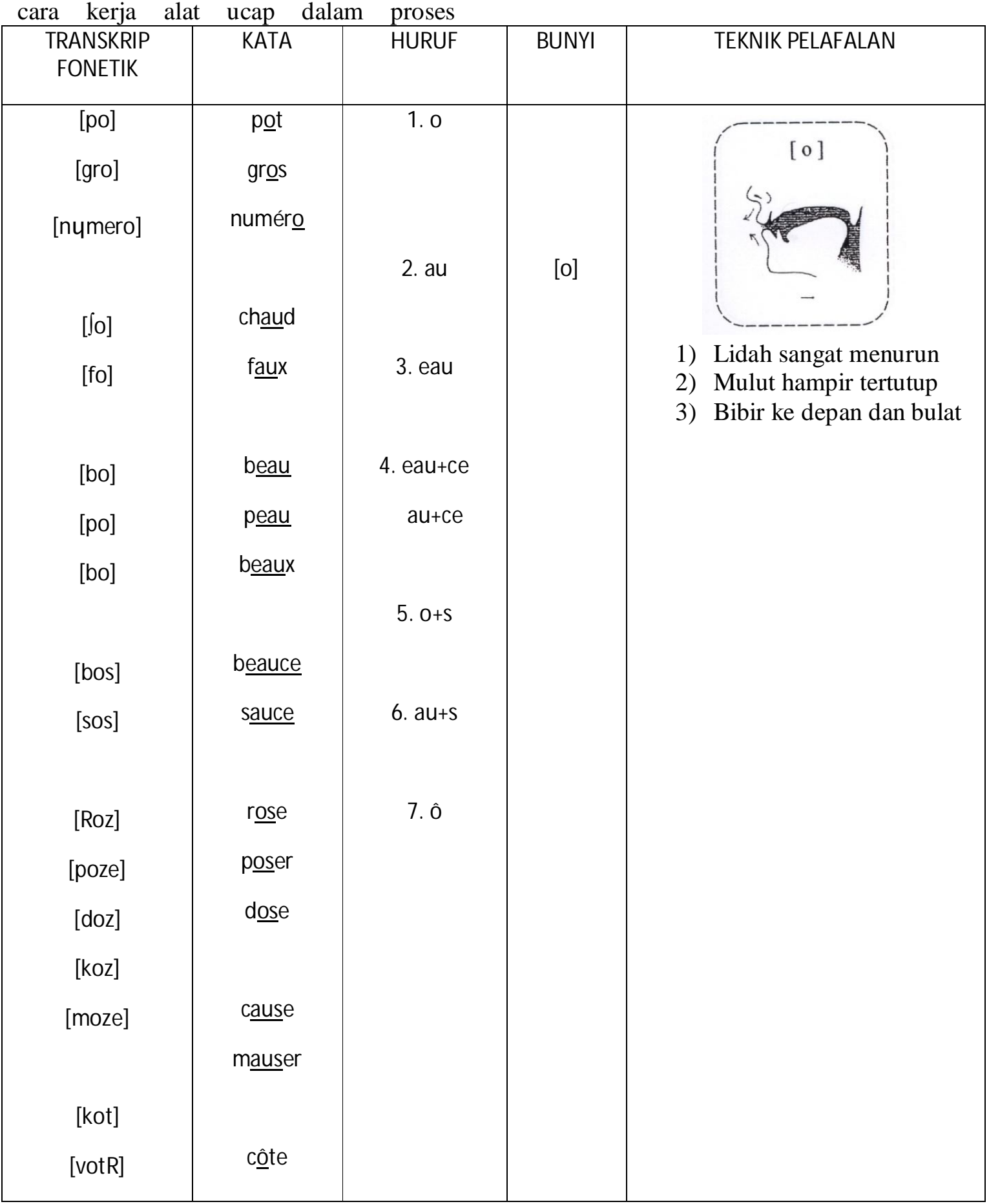

pembentukan atau produksi bunyi fonem, model artikulatoris pengembangan menampilkan juga kata dan kalimat bahasa Perancis yang dibentuk dari bunyi fonem beserta transkrip fonetiknya serta hubungan bunyi, huruf, dan pola huruf. Berikut ini adalah sebagian contoh model yang akan diujicobakan untuk pengajaran pelafalan bahasa Perancis: 
Soeprapto Rakhmat, dkk., Pembelajaran Pelafalan Bahasa Perancis

\begin{tabular}{|c|c|c|c|c|c|}
\hline [dRol] & $\begin{array}{l}\text { vôtre } \\
\text { drôle }\end{array}$ & & & & \\
\hline $\begin{array}{c}\text { [ublije] } \\
\text { [fu] } \\
\text { [suR] }\end{array}$ & $\begin{array}{l}\text { oublier } \\
\text { fou } \\
\text { sourd }\end{array}$ & 1. ou & {$[u]$} & & {$[u]$} \\
\hline $\begin{array}{c}{[u]} \\
{[k u t]} \\
{[g u]}\end{array}$ & $\begin{array}{l}\text { où } \\
\text { coûte } \\
\text { goût }\end{array}$ & $\begin{array}{l}\text { 2. où } \\
\text { 3. oû }\end{array}$ & & $\begin{array}{l}\text { 1) } \\
\text { 2) } \\
\text { 3) }\end{array}$ & $\begin{array}{l}\text { Lidah berada di } \\
\text { belakang, ujungnya } \\
\text { berada di bawah } \\
\text { Mulut hampir tertutup } \\
\text { Bibir dimajukan ke } \\
\text { depan }\end{array}$ \\
\hline $\begin{array}{c}\text { [fym] } \\
\text { [sy] } \\
\text { [ly] } \\
\text { [ny] }\end{array}$ & $\begin{array}{c}\text { fume } \\
\text { su } \\
\text { lü } \\
\text { nue }\end{array}$ & 1. u & [y] & & \\
\hline $\begin{array}{l}\text { [syR] } \\
\text { [dy] }\end{array}$ & $\begin{array}{l}\text { sûr } \\
\text { dûu }\end{array}$ & 2. û & & $\begin{array}{l}\text { 1) } \\
\text { 2) }\end{array}$ & $\begin{array}{l}\text { Lidah ditekan pada ujung } \\
\text { gigi bagian bawah } \\
\text { Mulut hampir tertutup }\end{array}$ \\
\hline $\begin{array}{c}\text { [nuzym] } \\
\text { [ilaØ] }\end{array}$ & $\begin{array}{c}\text { nous eûmes } \\
\text { il a eu }\end{array}$ & $\begin{array}{l}\text { 3. eû } \\
\text { Eu }\end{array}$ & & 3) & $\begin{array}{l}\text { Bibir dibulatkan } \\
\text { menempel pada gigi }\end{array}$ \\
\hline $\begin{array}{c}{[3 ə]} \\
{[\mathrm{m} ə]} \\
{[\mathrm{t} \partial]} \\
{[\mathrm{d} \partial \mathrm{v} \partial \mathrm{niR}]} \\
{[\mathrm{l} \partial \mathrm{ve}]}\end{array}$ & $\begin{array}{c}\text { je } \\
\text { me } \\
\text { te } \\
\text { devenir } \\
\text { lever }\end{array}$ & 1. $\mathrm{e}$ & {$[\partial]$} & 1) & $\begin{array}{l}\text { Lidah ditekan di antara } \\
\text { gigi bagian bawah }\end{array}$ \\
\hline
\end{tabular}


bahasa \& sastra, Vol. 15, No.1, April 2015

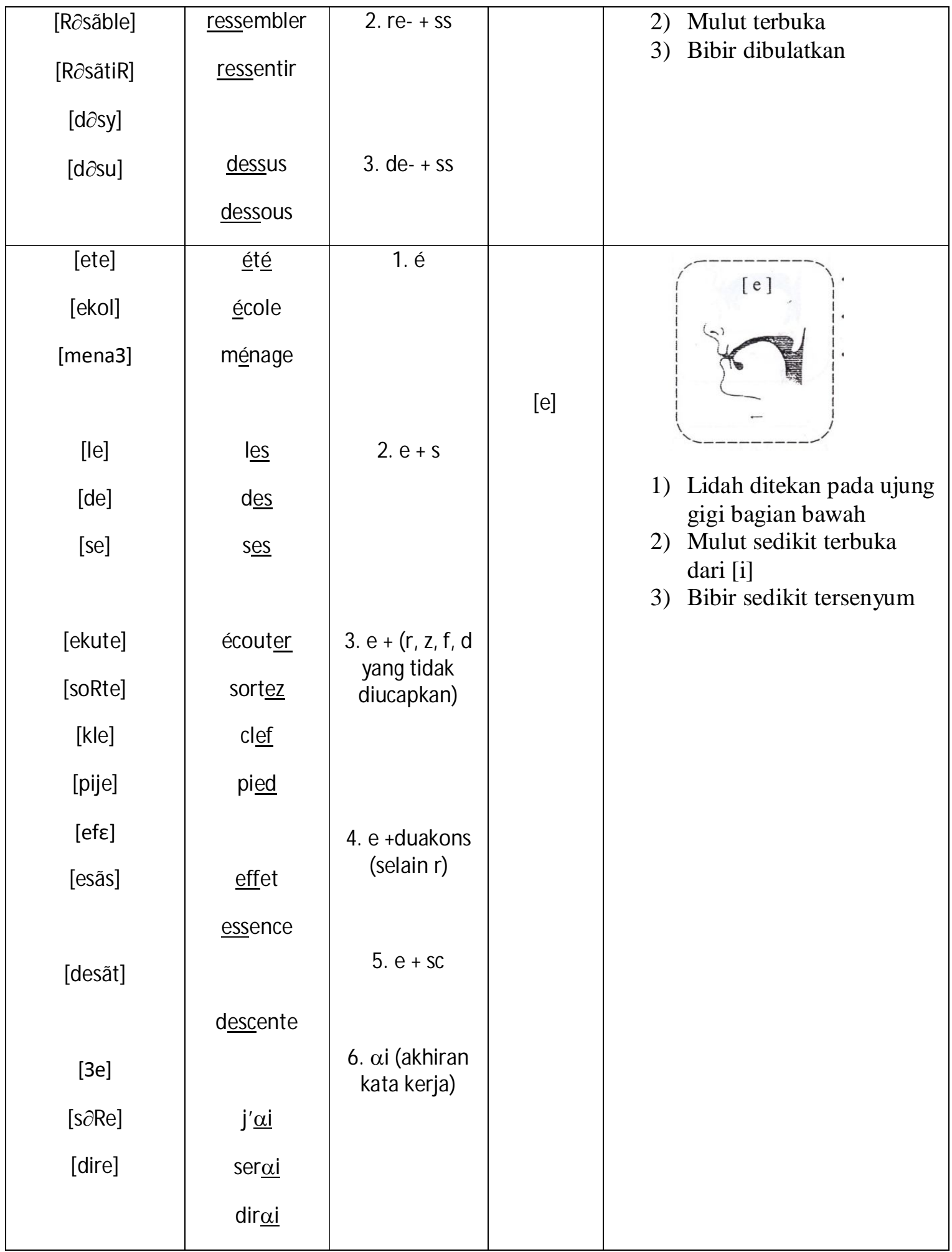

Dari hasil pengembangan yang belum diujicobakan secara komprehensif dan empiris tersebut, terdapat beberapa catatan penting hasil dari observasi, di antaranya, adalah (a) terdapat beberapa aspek yang perlu disempurnakan dalam Model Artikulatoris Pengembangan; dan (b) kurang optimalnya pemberian model 
pelafalan yang otentik mengingat pengajar bukanlah penutur asli bahasa Perancis. Oleh karena itu, diperlukan sebuah upaya untuk memecahkan beberapa permasalahan di atas, yaitu dengan merancang ulang dan mengembangkan Model Artikulatoris Pengembangan berbasis multimedia. Penggunaan teknologi multimedia adalah untuk mengembangkan dan memperkaya materi pembelajaran yang dapat memudahkan pembelajar serta memberikan pengalaman belajar pelafalan yang lebih otentik dengan berbasis kepada pemerolehan bahasa sebelumnya secara lebih optimal. Penggunaan media ini pun diharapkan dapat memotivasi pembelajar untuk mengeksplorasi materi dan memudahkan mereka dalam implementasi pembelajaran pelafalan.

$\begin{array}{lrr}\text { Sehubungan dengan } & \text { perancangan } \\ \text { model } & \text { pembelajaran } & \text { artikulatoris } \\ \text { pengembangan } & \text { (MAP) } & \text { berbasis }\end{array}$
multimedia CD-ROM interaktif, pelajaran bahasa Perancis dimulai dengan pengenalan fonem bahasa Perancis secara lepas. Tiap fonem diajarkan menurut bunyinya. Setelah itu, dikenalkan bunyi fonem bahasa Perancis yang lainnya ; $[\varepsilon]$, [e], [a], [o], [॰], [ə], [ø] dan seterusnya. Setelah siswa dapat melafalkan fonem Bahasa Perancis dengan benar dan dapat membedakan antara bunyi fonem satu dan lainnya, kemudian pengajar menampilkan daftar kata yang menggunakan bunyibunyi fonem yang telah dipelajari, misalnya : bunyi [e] dalam kata des [de], tes [te], mes [me], nez [ne], les [le], ces [se].Tahap akhir setelah siswa dapat melafalkan kata-kata yang dibentuk dengan bunyi-fonem yang telah dikenalnya, lalu kata-kata itu disusun menjadi kalimat. Tahap-tahap ini akan disajikan secara lebih rinci dalam CDROM interaktif di mana materi-materi pelafalan yang akan diberikan dibagi ke dalam beberapa bagian. Pembagian materi ini dikembangkan berdasarkan gradasi tingkat kesulitan. Di samping materi, media ini akan dilengkapi dengan support audio contoh-contoh bunyi hasil rekaman penutur asli yang disesuaikan dengan materi serta animasi gambar yang dapat memperjelas dan memotivasi pembelajar. Dengan demikian diharapkan pembelajar dapat lebih semangat belajar serta mendapatkan gambaran yang lebih untuk bisa melafalkan dengan baik.

Merujuk pada pemaparan di atas, penelitian ini bertujuan untuk menghasilkan model pembelajaran artikulatoris pengembangan (MAP) berbasis multimedia berdasarkan pemerolehan bahasa sebelumnya yang tepat guna dan efektif dalam pembelajaran pelafalan bahasa Perancis. Berdasarkan hal tersebut, peneliti tujuan khusus dari penelitian ini adalah untuk memperoleh informasi perihal: (1) perancangan dan pengembangan model MAP berbasis multimedia CD-ROM dalam pembelajaran pelafalan bahasa Perancis, (2) pemerolehan data empirik mengenai efektivitas dari penerapan model tersebut dalam pembelajaran pelafalan bahasa Perancis, (3) kendala yang dihadapi oleh para pembelajar selama proses pembelajaran.

\section{METODE}

Penelitian ini menggunakan
metode Research and Development
(R\&D). Pada tahap pengujian model,
peneliti melakukan eksperimen, yaitu
dengan cara membandingkan nilai
sebelum pemberian treatment dan sesudah
pemberian treatment pembelajaran.
Berikut ini desain eksperimen before-after
(Sugiyono, 2011).

$$
\mathrm{O}_{1} \quad \mathrm{X}_{2} \mathrm{O}_{2}
$$

Ket: $\mathrm{O}_{1}$ : Nilai sebelum treatment; $\mathrm{O}_{2}$ : Nilai sesudah treatment; $\mathrm{X}$ :Pelaksanaan treatment

Adapun langkah-langkah yang ditempuh dalam melaksanakan penelitian 
ini terdiri atas tiga tahap, yaitu : (1) studi pendahuluan, (2) perencanaan dan pengembangan model, dan (3) validasi model.Subjek penelitian ini adalah mahasiswa Departemen Pendidikan Bahasa Perancis FPBS UPI dengan mengambil sampel karakteristik kemampuan pelafalan mahasiswa semester I Departemen Pendidikan Bahasa Perancis FPBS UPI tahun akademik 2014/2015. Instrumen penelitian yang digunakan dalam penelitian ini adalah daftar kata, pasangan kata dalam klausa bahasa Perancis yang mewakili semua sistem bunyi yang ada dalam bahasa Perancis dan yang harus dilafalkan oleh seluruh subjek penelitian, serta tes pelafalan.

\section{HASIL DAN PEMBAHASAN}

Penelitian ini mengkaji proses penyusunan materi pelafalan bahasa Perancis berupa CD-Rom interaktif sekaligus mengujicobakannya kepada responden penelitian dalam hal ini mahasiswa semester I tahun akademik 2014/2015 yang merupakan pembelajar pemula bahasa Perancis sebagai upaya untuk memperoleh data perihal tingkat keefektifannya dalam proses pembelajaran pelafalan bahasa Perancis pada mata kuliah Communication Orale I.
Sekaitan isi materi pada CD-Rom, peneliti telah menyusunnya dengan didasarkan pada kompetensi bahasa Perancis tingkat dasar. Untuk pembuatan tampilan materi (story board) pada CDRom interaktif, peneliti telah bekerjasama dengan pihak Direktorat Teknologi Informasi dan Komunikasi UPI (Direktorat TIK UPI). Proses penyusunan materi dari mulai inventarisir buku dan sumber lainnya telah peneliti lakukan mulai bulan juni hingga Juli 2014. Selanjutnya, pengisian suara untuk CD-Rom tersebut dilakukan pada bulan Agustus dengan melibatkan seorang native speaker (penutur asli) bahasa Perancis yaitu Vanessa Lesage.

Program CD ROM pembelajaran pelafalan dengan menggunakan Model Artikulatoris Pengembangan diberinama "SAVOIR PRONONCER". Program ini disusun oleh tim peneliti bekerjasama dengan Direktorat TIK UPI.Di dalam CDROM berbasisteknologiFlash initerdapat 4 (empat) menu utama, yaitu: "Alphabet Français", "Les Sons (Voyelles)", "Les Sons (Consonnes)", dan "Les Sons Semi Voyelles/ Consonnes". Berikut ini adalah tampilan muka CD-ROM untuk semua menu:

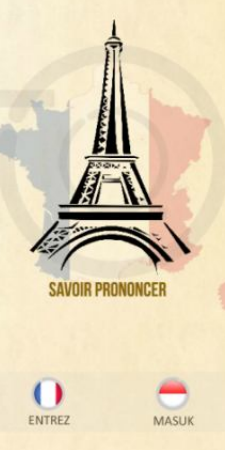

Gambar 1. Halaman muka CD-ROM 


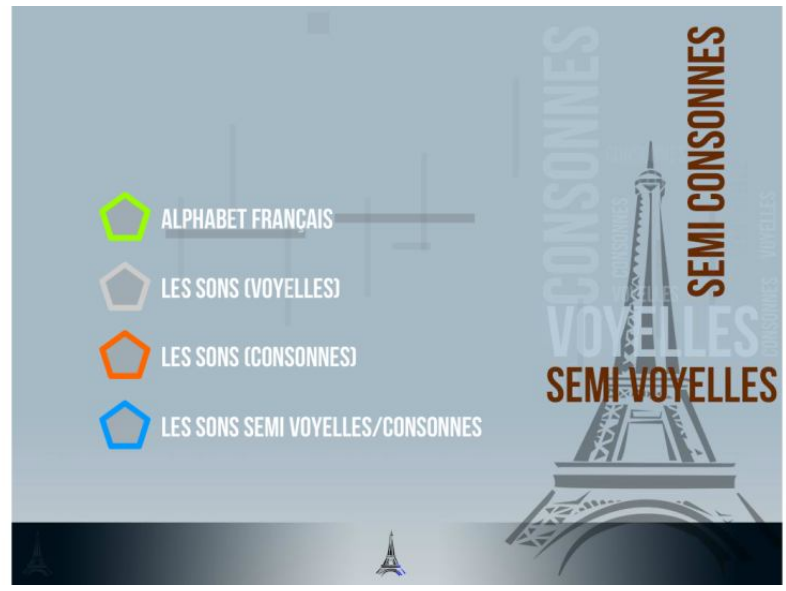

Gambar 2. Halaman peta menu isi program CD-ROM

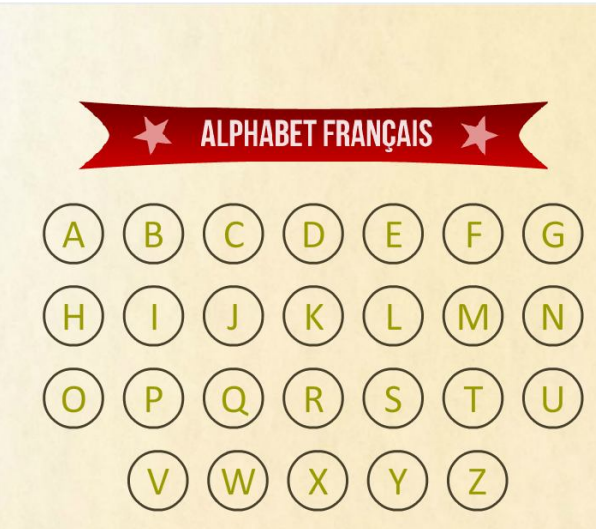

0

Gambar 3. Halaman peta menu "Alphabet Français"

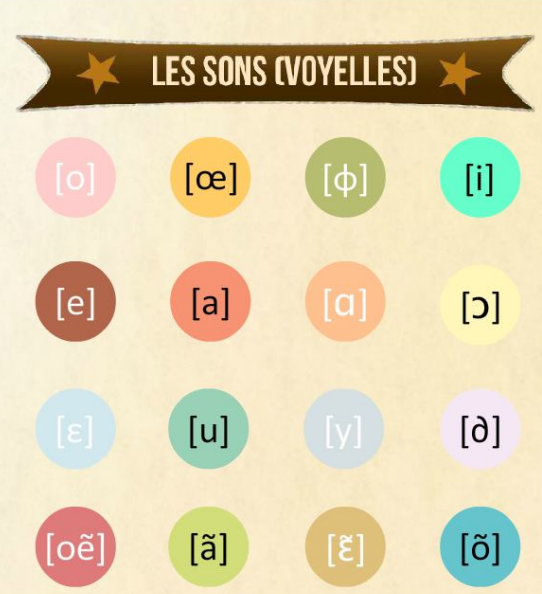

Gambar 4. Halaman menu "Les Sons Voyelles" 
bahasa \& sastra, Vol. 15, No.1, April 2015

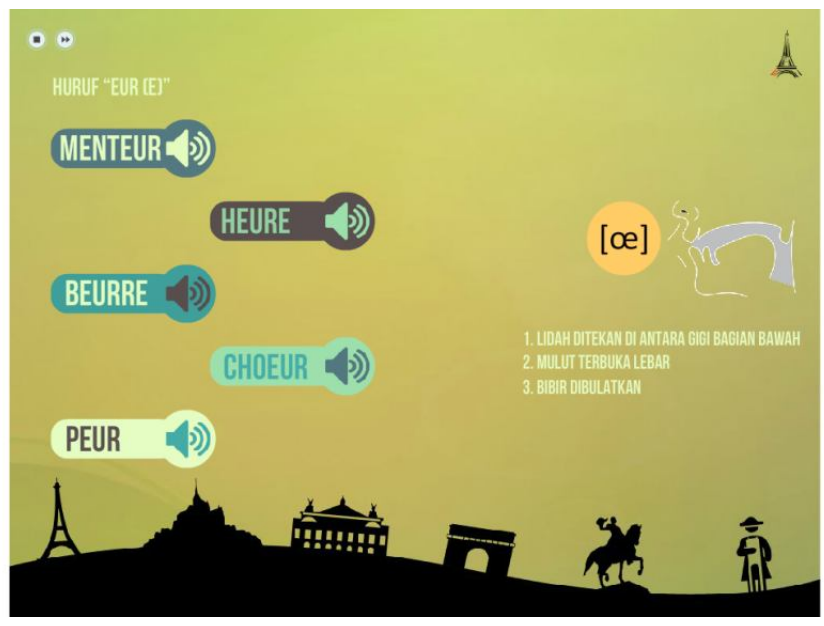

Gambar 5. Halaman konten "Les Sons Voyelles"

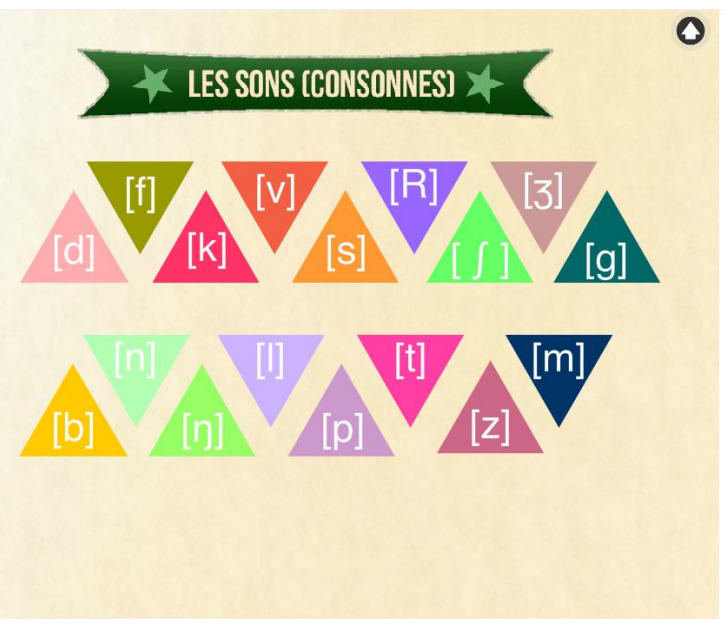

Gambar 6. Halaman menu "Les Sons Consonnes"

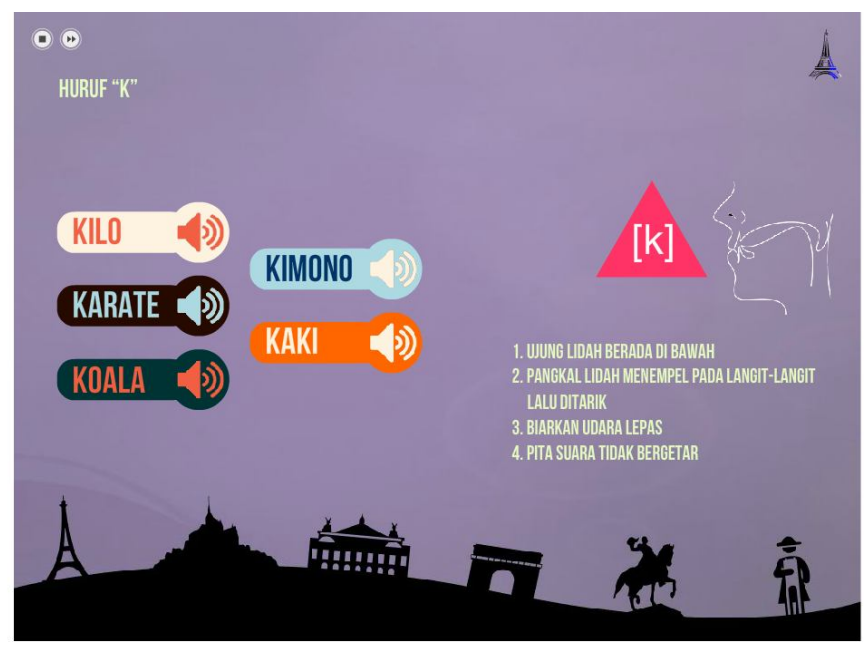

Gambar 7. Halaman konten "Les Sons Consonnes" 


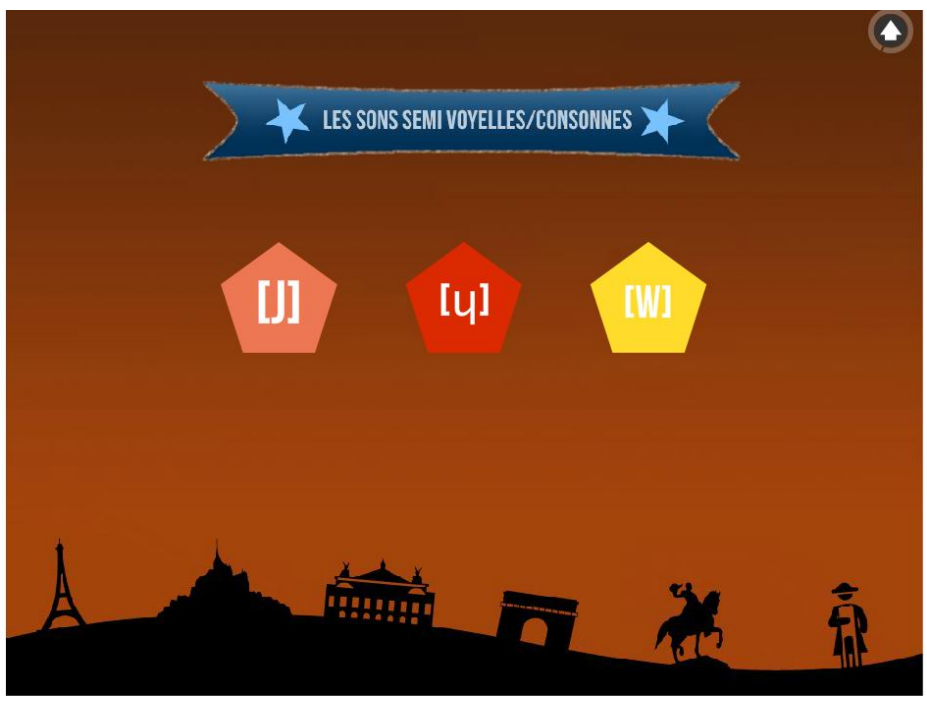

Gambar 8. Halaman menu "Les Sons Semi Voyelles/Consonnes"

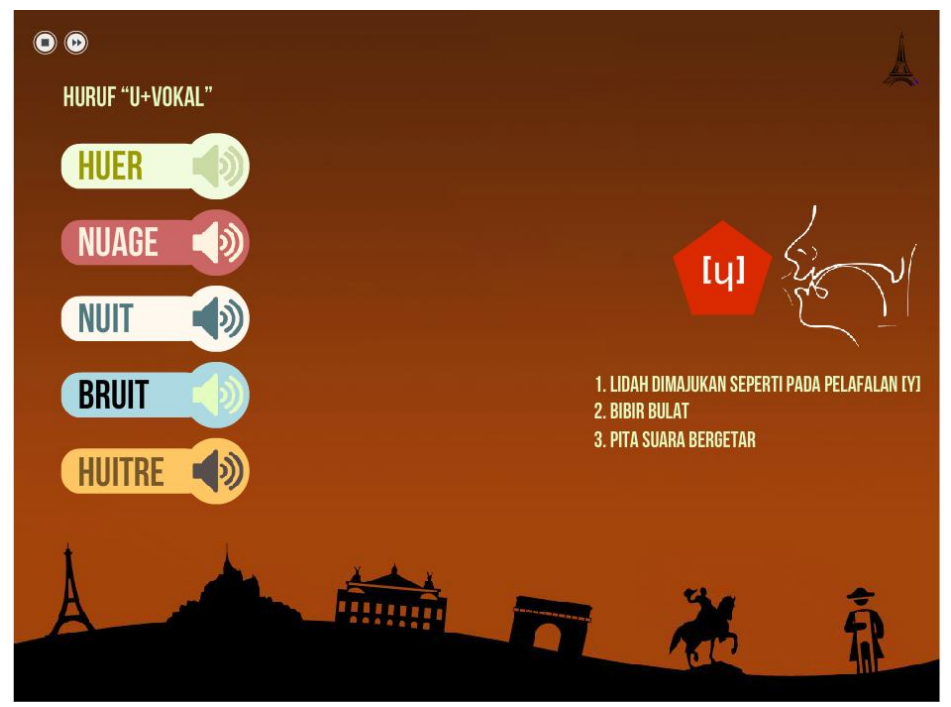

Gambar 9. Halaman konten "Les Sons Semi Voyelles/Consonnes"

Pascapenyusunan materi pembelajaran pelafalan dan disertai $\mathrm{CD}$ Rom interaktif, tahap selanjutnya yang dilakukan adalah proses pengambilan data prates pada sampel penelitian yaitu 32 orang mahasiswa semester I di
Departemen Pendidikan Bahasa Perancis FPBS UPI. Nilai total prates adalah sebesar 40 poin. Pengambilan data prates dilaksanakan pada tanggal18 September 2014berikut ini nilai hasil prates dan distribusi frekuensi nilai prates. 
Tabel 1. Nilai prates pelafalan bahasa Perancis

\begin{tabular}{cccccc}
\hline $\begin{array}{c}\text { Nomor } \\
\text { Responden }\end{array}$ & NIM & Nilai Prates & $\begin{array}{c}\text { Nomor } \\
\text { Responden }\end{array}$ & NIM & Nilai Prates \\
\hline 1 & 1400880 & 33 & 17 & 1404267 & 28 \\
\hline 2 & 1401083 & 28 & 18 & 1404292 & 28 \\
\hline 3 & 1401105 & 34 & 19 & 1404350 & 32 \\
\hline 4 & 1401225 & 28 & 20 & 1404372 & 32 \\
\hline 5 & 1401340 & 28 & 21 & 1404405 & 32 \\
\hline 6 & 1401504 & 26 & 22 & 1404634 & 30 \\
\hline 7 & 1401600 & 28 & 23 & 1404754 & 34 \\
\hline 8 & 1401643 & 25 & 24 & 1404913 & 34 \\
\hline 9 & 1401749 & 30 & 25 & 1405176 & 32 \\
\hline 10 & 1401860 & 32 & 26 & 1405529 & 32 \\
\hline 11 & 1401861 & 30 & 27 & 1405989 & 34 \\
\hline 12 & 1401869 & 28 & 28 & 1406163 & 34 \\
\hline 13 & 1401934 & 28 & 29 & 1406327 & 35 \\
\hline 14 & 1404134 & 30 & 30 & 1406490 & 38 \\
\hline 15 & 1404164 & 32 & 31 & 1406896 & 32 \\
\hline 16 & 1404205 & 32 & 32 & 1407089 & 30 \\
\hline
\end{tabular}

Tabel 2. Distribusi frekuensi bergolong nilai prates

\begin{tabular}{ccc}
\hline Rentang Nilai & f & \% \\
\hline $35-40$ & 1 & $3,12 \%$ \\
\hline $30-35$ & 16 & $50 \%$ \\
\hline $25-30$ & 14 & $43,75 \%$ \\
\hline $20-25$ & 1 & $3,12 \%$ \\
\hline$\ldots-20$ & 0 & $0 \%$ \\
\hline
\end{tabular}

Setelah pengambilan data prates peneliti melakukan treatment pembelajaran pelafalan untuk melatih mahasiswa dalam pelafalan sejumlah kata dalam bahasa Perancis. Proses pelaksanaan treatment dilakukan pada tanggal 6,7 , dan 8 Oktober 2014. Materi yang diberikan pada saat treatment merujuk pada materi yang ada pada CD-Rom yang telah disusun peneliti.
Pascapemberian treatment, peneliti melakukan pengambilan data pascates untuk memperoleh data perihal kemampuan pelafalan mahasiswa pascapemberian treatment. Pascates dilakukan pada tanggal 20 November 2014. Berikut ini hasil data pascates dan distribusi frekuensi nilai pascates. 
Tabel 3. Nilai pascates pelafalan bahasa Perancis

\begin{tabular}{cccccc}
\hline $\begin{array}{c}\text { Nomor } \\
\text { Responden }\end{array}$ & NIM & $\begin{array}{c}\text { Nilai } \\
\text { Pascates }\end{array}$ & $\begin{array}{c}\text { Nomor } \\
\text { Responden }\end{array}$ & NIM & $\begin{array}{c}\text { Nilai } \\
\text { Pascates }\end{array}$ \\
\hline 1 & 1400880 & 38 & 17 & 1404267 & 34 \\
\hline 2 & 1401083 & 33 & 18 & 1404292 & 33 \\
\hline 3 & 1401105 & 38 & 19 & 1404350 & 35 \\
\hline 4 & 1401225 & 33 & 20 & 1404372 & 38 \\
\hline 5 & 1401340 & 34 & 21 & 1404405 & 37 \\
\hline 6 & 1401504 & 32 & 22 & 1404634 & 34 \\
\hline 7 & 1401600 & 35 & 23 & 1404754 & 38 \\
\hline 8 & 1401643 & 34 & 24 & 1404913 & 35 \\
\hline 9 & 1401749 & 33 & 25 & 1405176 & 38 \\
\hline 10 & 1401860 & 34 & 26 & 1405529 & 36 \\
\hline 11 & 1401861 & 33 & 27 & 1405989 & 38 \\
\hline 12 & 1401869 & 32 & 28 & 1406163 & 38 \\
\hline 13 & 1401934 & 37 & 29 & 1406327 & 37 \\
\hline 14 & 1404134 & 35 & 30 & 1406490 & 40 \\
\hline 15 & 1404164 & 37 & 31 & 1406896 & 36 \\
\hline 16 & 1404205 & 39 & 32 & 1407089 & 35 \\
\hline
\end{tabular}

Tabel 4. Distribusi frekuensi bergolong nilai pascates

\begin{tabular}{ccc}
\hline Rentang Nilai & f & \% \\
\hline $35-40$ & 15 & $46,88 \%$ \\
\hline $30-35$ & 17 & $53,12 \%$ \\
\hline $25-30$ & 0 & $0 \%$ \\
\hline $20-25$ & 0 & $0 \%$ \\
\hline$\ldots-20$ & 0 & $0 \%$ \\
\hline
\end{tabular}

Pascapengambilan data prates dan pascates, dapat peneliti simpulkan bahwa mahasiswa/responden masih banyak melakukan kesalahan baik dalam pelafalan bunyi fonem/alphabet tertentu, kata maupun pasangan kata secara spontan. Hal ini dapat dibuktikan berdasarkan pada hasil analisis data prates.

1. Melafalkan alphabet/fonem

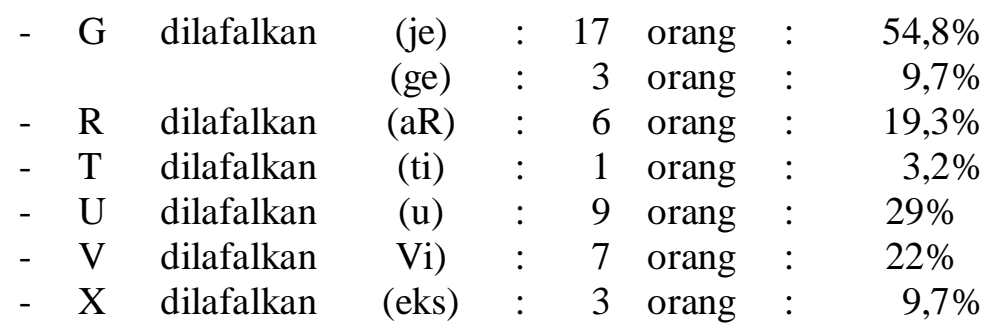


2. Melafalkan kata

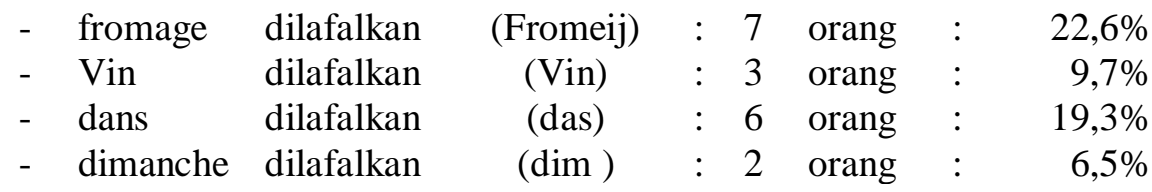

3. Melafalkan pasangan kata

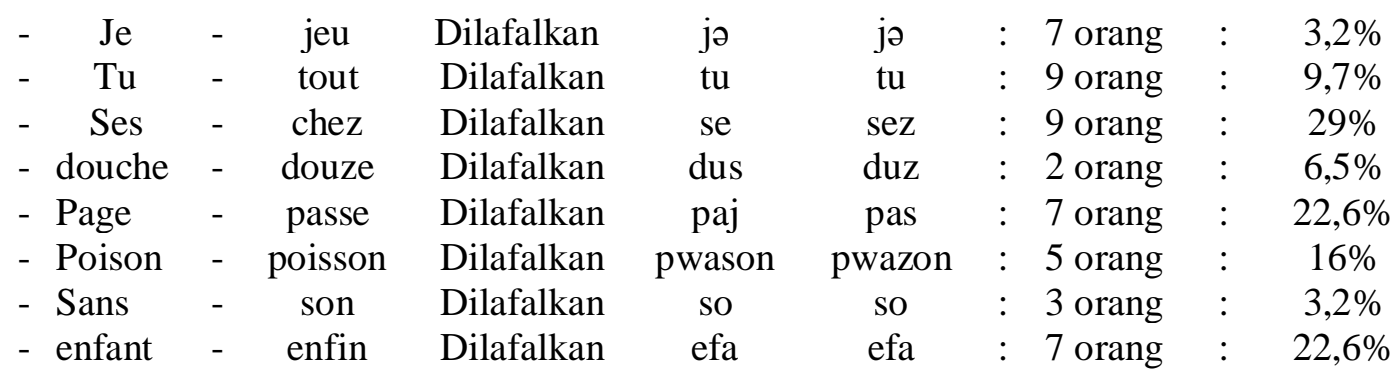

Mengacu pada hasil analisis data prates di atas, diperoleh data bahwa khusus untuk pelafalan pasangan kata diperoleh data bahwa, (1) Mahasiswa belum dapat membedakan antara bunyi [ə] dan [ø], (2) Mahasiswa belum dapat membedakan antara bunyi [u] dan [u], (3) Mahasiswa belum dapat membedakan antara bunyi [s] dan [J], (4) Mahasiswa belum dapat membedakan antara bunyi [ $\left.\int\right]$ dan [z], (5) Mahasiswa belum dapat membedakan antara bunyi [3] dan [s], (6) Mahasiswa belum dapat membedakan antara bunyi [z] dan [s], (7) Mahasiswa belum dapat membedakan antara bunyi [ã] dan [õ], (8) Mahasiswa belum dapat membedakan antara bunyi [ã] dan $[\varepsilon]$.

Untuk memperoleh informasi perihal efektivitas model MAP berbasis CD-Rom interaktif, pascates dilakukan peneliti untuk mengevaluasinya. Berikut ini hasil analisis data pascates.

1. Pelafalan alphabet/fonem

$\begin{array}{ccccccccc}\text { - } & \mathrm{G} & \text { dilafalkan } & {[\mathrm{je}]} & : & 7 & \text { orang } & : & 22,6 \% \\ & & & {[\mathrm{ge}]} & : & 1 & \text { orang } & : & 3,2 \% \\ \text { - } & \mathrm{R} & \text { dilafalkan } & {[\mathrm{aR}]} & : & 2 & \text { orang } & : & 6,5 \% \\ \text { - } & \mathrm{U} & \text { dilafalkan } & {[\mathrm{u}]} & : & 6 & \text { orang } & : & 19,7 \% \\ \text { - } & \mathrm{V} & \text { dilafalkan } & {[\mathrm{Vi}]} & : & 2 & \text { orang } & : & 6,5 \% \\ \text { - } & \mathrm{X} & \text { dilafalkan } & {[\mathrm{eks}]} & : & 1 & \text { orang } & : & 3,2 \%\end{array}$

2. Melafalkan kata

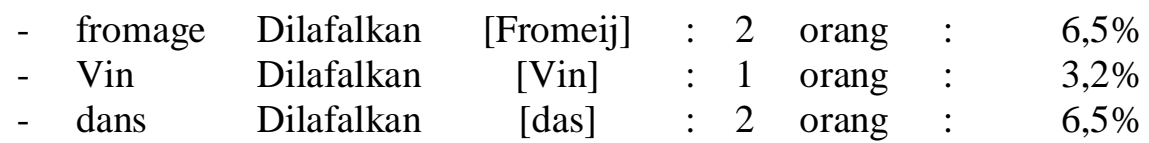


3. Melafalkan pasangan kata

$\begin{array}{llcccccccc}\text { - Je } & - & \text { jeu } & \text { dilafalkan } & {[j ə]} & {[j ə]} & : & 3 \text { orang } & : & 9,7 \% \\ \text { - Tu } & - & \text { tout } & \text { dilafalkan } & {[\mathrm{tu}]} & {[\mathrm{tu}]} & : & 2 \text { orang } & : & 6,5 \% \\ \text { - Ses } & - & \text { chez } & \text { dilafalkan } & \text { [se] } & {[\mathrm{sez}]} & : & 1 \text { orang } & : & 3,2 \% \\ \text { - douche } & - & \text { dowze } & \text { dilafalkan } & \text { [dus] } & {[\mathrm{duz}]} & : & 1 \text { orang } & : & 3,2 \% \\ \text { - Page } & - & \text { passé } & \text { dilafalkan } & \text { [paj] } & \text { [pas] } & : & 4 \text { orang } & : & 13 \% \\ \text { - Poison } & - & \text { poishon } & \text { dilafalkan } & \text { [pwason] } & \text { [pwazon] } & : & 2 \text { orang } & : & 6,5 \% \\ \text { - Sars } & - & \text { sor } & \text { dilafalkan } & \text { [so] } & \text { [so] } & : & 1 \text { orang } & : & 3,2 \% \\ \text { - enfant } & - & \text { enfin } & \text { dilafalkan } & \text { [efa] } & \text { [efa] } & : & 4 \text { orang } & : & 13 \%\end{array}$

Merujuk pada data nilai hasil prates dan pascates, peneliti dapat mengungkapkan bahwa mahasiswa mengalami kemajuan yang signifikan dalam melafalkan alfabet/fonem, kata dan pasangan kata setelah mereka menerima tiga kali perlakuan (treatment) MAP. Hal ini terbukti dari derajat persentase sebagai berikut.

Tabel 5. Rekapitulasi data hasil prates dan pascates

\begin{tabular}{llcccc}
\hline \multirow{2}{*}{ Aspek Pelafalan } & \multicolumn{2}{c}{ Prates } & \multicolumn{2}{c}{ Pascates } \\
\cline { 3 - 5 } & Ketidaktepatan & Ketepatan & Ketidaktepatan & Ketepatan \\
\hline 1 & Alfabet/fonem & $25,7 \%$ & $74,3 \%$ & $13 \%$ & $87 \%$ \\
2 & Kata & $14,1 \%$ & $85,9 \%$ & $9,7 \%$ & $90,3 \%$ \\
3 & Pasangan kata & $54,8 \%$ & $45,2 \%$ & $32,2 \%$ & $67,8 \%$ \\
\hline
\end{tabular}

Dari data di atas dapat dipahami bahwa kesalahan/ ketidaktepatan pelafalan untuk ketiga aspek (aspek alphabet/fonem, kata, pasangan kata) di atas disebabkan oleh beberapa faktor, diantaranya dua factor yang paling dominan yaitu: (1)Pengaruh bahasa naasional (Indonesia) dan atau daerah terutama bahasa Sunda. Masih terdapat beberapa orang mahasiswa yang belum dapat melafalkan bunyi, ( u ) dan (u). Hal ini dikarenakandalam bahasa Indonesia dan bahasa Sunda tidak terdapat bunyi fonem (u), sehingga tidak terbiasa melafalkannya., (2) Pengaruh bahasa Inggris, seperti huruf ( a ) dilafalkan ( e ), akhiran "s" dalam sebuah kata sebagai penanda jamak dilafalkan fonem "s" nya, sedangkan dalam bahasa Perancis tidak dilafalkan.

\section{SIMPULAN}

Bahasa Perancis merupakan salah satu bahasa asing yang dipelajari mahasiswa setelahpenguasaan bahasa ibu dan bahkan bahasa asing lainnya seperti bahasa Inggris mempunyai sistem bunyi yang sangat berbeda. Bertitiktolak dari sistem bunyi yang berbeda kesulitan pertama yang mereka temukan dalam mempelajari bahasa Perancis adalah melafalkan bunyi fonem.

Model

Artikulatoris Pengembangan (MAP) berbasis multimedia (CD-Rom) yang digunakan dalam penelitian ini telah diaplikasikan dengan tujuan mengatasi kesulitan di atas. Model ini diterapkan melalui tahapan: (1) Penayangan MAP yang berisi materi dalam CD-ROM berbasis teknologi Flash ini terdapat 4 (empat) menu utama, yaitu: 
"Alphabet Français", "Les Sons (Voyelles)", "Les Sons (Consonnes)", dan "Les Sons Semi Voyelles/Consonnes"; (2) Peneliti mengoperasikan alat untuk menayangkan materi secara audio visual sesuai dengan tahapan berisi 4 (empat) menu MAP sekaligus menjelaskan hubungan bunyi dengan huruf dalam tataran kata; (3) Mahasiswa menirukan bunyi yang diperdengarkan secara berulang; (4) Peneliti mengoreksi secara langsung individual pelafalan mahasiswa yang keliru/salah; dan (5) Peneliti melakukan refleksi terhadap penerapan MAP.

Berdasarkan data yang diperoleh dari hasil tes pelafalan mahasiswa (pra-tes dan pasca-tes), dapat disimpulkan terdapat hasil yang signifikan.Hal ini dibuktikan dengan data pemerolehan nilai tinggi (rentang skor 30 - 40) prates sebesar $53,12 \%$, menjadi $100 \%$ pada hasil pascates. Hal ini berarti terdapat peningkatan sebesar $46,88 \%$. Oleh karena itu, dapat disimpulkan bahwa MAP berbasis multimedia CD-ROM efektif diterapkan pada pembelajaran pelafalan bahasa Perancis.

Dari hasil tes pelafalan baik prates maupun pascates mahasiswa masih melakukan 2 (dua) jenis kesalahan, yaitu secara fonologis dan secara artikulatoris. Kedua kesalahan tersebut diakibatkan oleh kesulitan mahasiswa dalam melafalkan $[\mu],[\varnothing], \quad[\tilde{o}] \quad[\tilde{a}],[\varepsilon], \quad\left[\int\right],[v],[z] . K e s u l i t a n$ secara fonologis dipengaruhi oleh penguasaan bahasa sebelumnya, sementara kesalahan secara artikulatoris mahasiswa tidak memfungsikan alat ucap secara tepat dan optimal.

\section{UCAPAN TERIMA KASIH}

Peneliti mengucapkan terima kasih kepada berbagai pihak yang telah membantu proses pelaksanaan penelitian ini, di antaranya kepada pihak LPPM UPI dan DP2M Dikti yang telah membantu dalam pendanaan penelitian ini. Selain itu, ucapan terima kasih disampaikan kepada pimpinan Fakultas Pendidikan Bahasa dan Sastra dan pimpinan Departemen Pendidikan Bahasa Perancis Universitas Pendidikan Indonesia yang telah membantu dalam penyediaan lokasi dan fasilitas pelaksanaan penelitian. Untuk pengisi suara penutur asli pada CD-Rom interaktif yang disusun, peneliti mengucapkan terima kasih kepada Vannessa Lesage atas kesediaannya.

\section{DAFTAR PUSTAKA}

Gardes-Tamine, J.(1990). De la Linguistique à la Pédagogique. Paris: Hachette Larousse.

Mutiarsih,Y.(2009). "Model Artikulatoris Pengembangan untuk Meningkatkan Kemampuan Berbicara bahasa Perancis Siswa SMA dan SMK di Kota dan Kabupaten Bandung". Laporan Penelitian Hibah Bersaing DIKTI-UPI : Tidak diterbitkan.

Robert. (2006) Le Robert Micro Dictionnaire De La Langue Française. Italie : La Tipografica Varese.

Sugiyono. (2011). Metode Penelitian Kuantitatif, Kualitatif dan $R \& D$. Bandung: Alfabeta 